\title{
EVENT STUDY: REAKSI PASAR TERHADAP PENGUMUMAN DIVIDEN PADA PERUSAHAAN YANG TERDAFTAR DI BURSA EFEK INDONESIA
}

\author{
AFNI ELIANA SARAGIH \\ Dosen Program Studi Akuntansi Fakultas Ekonomi Universitas Katolik Santo Thomas \\ E-mail : afni.eliana@yahoo.com
}

\begin{abstract}
Abstrak
Pengumuman dividen diprediksi mengandung informasi dimana manajer menggunakan pengumuman dividen untuk memberikan signal kepada pihak eksternal akan perubahan harapan (expectation) terkait masa depan perusahaan. Informasi yang terkandung dalam pengumuman dividen dapat mempengaruhi investor mengubah keputusannya dan akan mempengaruhi harga dan volume perdagangan saham perusahaan.Penelitian ini bertujuan untuk menganalisis pengaruh pengumuman dividen terhadap abnormal return dan volume perdagangan saham pada perusahaan yang terdaftar di Bursa Efek Indonesia. Metode penelitian yang digunakan adalah event study dengan mengambil pengumuman dividensebagai event. Event studyakan melihat apakah harga saham mengalami peningkatan atau mengalami penurunan setelah suatu peristiwa terjadi. Hasil penelitian menemukan bahwa terdapat pengaruh pengumuman dividen terhadap abnormal return ditunjukkan dengan nilai CAAR yang positif dan signifikan. Hasil pengamatan juga menunjukkan nilai ATVA yang positif dan signifikan.
\end{abstract}

Kata kunci: Pengumuman Dividen, Abnormal Return, Trading Volume Activity

\section{PENDAHULUAN}

Berbagai informasi yang diterbitkan oleh perusahaan akan direspon oleh investor dapat berupa peningkatan atau penurunan harga dan volume perdagangan saham. Informasi bahwa perusahaan akan membagikan dividen merupakan salah satu faktor yang akan mempengaruhi harga dan volume perdagangan saham. Dividen merupakan jumlah tertentu dari laba perusahan yang dibagikan kepada pemegang saham (investor).

Reaksi pasar modal terhadap kandungan informasi dalam suatu peristiwa dapat diukur dengan menggunakan returnsebagai nilai perubahan harga atau dengan menggunakan abnormal return yang merupakan selisih antara returnrealisasi dengan returnyang diekspektasikan oleh investor (Jogiyanto, 2012). Selain menggunakan abnormal return, reaksi pasar terhadap informasi juga dapat dilihat melalui parameter pergerakan aktivitas volume perdagangan di pasar (Trading Volume Activity) (Foster, 1986).Beberapa penelitian menggunakan abnormal return dan volume perdagangan sebagai variabel penelitian untuk menguji pengaruh suatu 
informasi yang dipublikasikan diantaranya Menike (2014) Dharmarathne (2013), Sadikin (2011), Ratnawati dkk.(2009), Siaputra dan Atmadja (2006), Sularso (2003).

Penelitian terdahulu menunjukkan bahwa dividen memainkan peranan penting sebagai informasi yang mempengaruhi pasar modal di berbagai negara. Berdasarkan informasi yang terkandung dalam dividend hypothesis (Fama et al., 1969), pengumuman dividen diprediksi mengandung informasi dimana manajer menggunakan pengumuman dividen kas untuk memberikan signal kepada pihak eksternal akan perubahan harapan (expectation) terkait masa depan perusahaan. Informasi yang terkandung dalam pengumuman dividen dapat mempengaruhi investor mengubah keputusannya dan akan mempengaruhi harga saham perusahaan.

Hasil penelitian sebelumnya (Aharony dan Swary, 1980) ditemukan bahwa pengumuman peningkatan jumlah dividen berpengaruh terhadap abnormal return yang positif dan pengumuman jumlah dividen yang menurun akanmenyebabkan terjadi abnormal return yang negative. Efisiensi pasar bentuk semi-kuat (semi strong form efficient market hypothesis) menurut Fama (1970) menegaskan bahwa pengumuman suatu informasi seharusnya direspon pasar secara cepat dan tepat yang terlihat dari harga pasar.

Asquith dan Mullins (1983) melakukan penelitian untuk melihat respon pasar atas pengumuman dividen baik pengumuman pembagian dividen perdana maupun yang bekelanjutan di U.S. Hasil penelitiannya menemukan terdapat dua hari abnormal return yang positif atas pengumuman pembagian dividen untuk pertama sekali oleh perusahaan. Selain itu penelitian ini menemukan bahwa reaksi pasar terhadap pengumuman dividen perdana lebih besar dibandingkan dengan reaksi pasar terhadap pengumuman dividen yang telah berulang. Hasil penelitian juga mendukung bentuk pasar semi-kuat.

Kaestner dan Lui (1998) menemukan hasil penelitian yang lebih komprehensif dengan menguji hubungan pengumuman dividen dengan harga pasar.Secara berkesinambungan mereka menguji beberapa teori terkait informasi yang terkandung pada pengumuman dividen dengan menggunakan dua jenis pengumuman, yaitu dividen perdana dan dividen yang didesain secara khusus. Hasil penelitian menemukan dukungan yang kuat untuk satu signal yaitu hipotesis signal arus kas (cash flow signaling hypothesis) dan tidak terlalu mendukung model sinyal yang beragam(multiple signal cash-flow signaling model). Selain itu ditemukan 
bahwa jumlah dividen yang dibagikan merupakan penentu utama dan paling konsisten mempengaruhi respon harga saham atas pengumuman dividen.

Tujuan utama penelitian ini adalah untuk menguji informasi yang terkandung dalam pengumuman dividend dan menguji efisiensi pasar bentuk semi-kuat di Indonesia dengan kondisi pasar modal yang berbeda dengan kondisi pasar modal asing. Penelitian ini akan menggunakan event studyuntuk tujuan tersebut. Sedangkan untuk menguji ada atau tidaknya abnormal return di sekitar pengumuman dividen akan dihitung menggunakan model pasar (market model).

\section{TINJAUAN PUSTAKA DAN PENGEMBANGAN HIPOTESIS}

\subsection{Efficient Market Hypothesis}

Secara formal pasar modal yang efisien didefenisikan sebagai pasar yang harga sekuritas-sekuritasnya telah mencerminkan semua informasi yang relevan.Semakin cepat informasi baru tercermin pada harga sekuritas, semakin efisien pasar modal tersebut. Dengan demikian akan sangat sulit bagi para investor untuk memperoleh tingkat keuntungan di atas normal secara konsisten dengan melakukan transaksi perdagangan di bursa efek. Tingkat keuntungan di atas normal diperoleh apabila tingkat keuntungan yang direalisasi lebih tinggi dibandingkan tingkat keuntungan ekuilibrum.Efisiensi dalam artian ini sering juga disebut sebagai efisiensi secara informasi (Husnan, 2005).

Jika pasar bereaksi terhadap suatu informasi untuk mencapai harga keseimbangan yang baru yang sepenuhnya mencerminkan informasi yang tersedia, maka kondisi pasar seperti ini disebut dengan pasar efisien.Dengan demikian terdapat hubungan antara teori pasar modal yang menjelaskan tentang keadaan ekuilibrum dengan konsep pasar efisien yang mencoba menjelaskan bagaimana pasar memproses informasi untuk menuju ke posisi ekuilibrum yang baru.Efisiensi pasar yang demikian disebut denan efisiensi pasar secara informasi (Informationally Efficient Market) yaitu bagaimana pasar bereaksi terhadap informasi yang tersedia (Jogiyanto, 2012).

Menurut Fama (1991) dalam Gumanti dan Utami (2002) menyatakan bahwa terdapat tiga bentuk efisiensi pasar. Bentuk pasar tersebut antara lain:

1. Hipotesis Pasar Efisien Bentuk Lemah (Weak Form)

Dalam hipotesis ini harga saham diasumsikan mencerminkan semua informasiyang terkandung dalam sejarah masa lalu tentang harga 
sekuritas yang bersangkutan.Artinya, harga yang terbentuk atas suatu saham, merupakan cermin daripergerakan harga saham yang bersangkutan di masa lalu.

\section{Hipotesis Pasar Efisien Bentuk Semi-Kuat (Semi-Strong Form)}

Menurut hipotesis pasar efisien bentuk semi-kuat, dalam Fama(1991) menyebutnya sebagai studi peristiwa (event studies), harga mencerminkansemua informasi publik yang relevan. Di samping merupakan cerminan harga sahamhistoris, harga yang tercipta juga terjadi karena informasi yang ada di pasar, termasuk

di dalamnya adalah laporan keuangan dan informasi tambahan (pelengkap)sebagaimana diwajibkan oleh peraturan akuntansi. Informasi yang tersedia di publikjuga dapat berupa peraturan keuangan lain seperti pajak bangunan (property) atausuku bunga dan/atau beta saham termasuk rating perusahaan.

\section{Hipotesis Pasar Efisien Bentuk Kuat (Strong Form)}

Pasar efisien bentuk kuat menyatakan bahwa harga yang terjadi mencerminkansemua informasi yang ada, baik informasi publik (public information) maupuninformasi pribadi (private information).Jadi, dalam hal ini, bentuk kuat mencakupsemua informasi historis yang relevan dan juga informasi yang ada di publik yangrelevan, disamping juga informasi yang hanya diketahui oleh beberapa pihak saja,misalnya manajemen perusahaan, dewan direksi, dan kreditor.

\subsection{Teori Sinyal (Signalling Theory)}

Secara umum, sinyal diartikan sebagai isyarat yang dilakukan oleh perusahaan yaitu manajer kepada pihak lain yang di luar perusahaan seperti investor dan pemangku kepentingan lainnya. Sinyal ini dimaksudkan untuk menyiratkan sesuatu dengan harapan penilaian pasar atau pihak eksternal akan perusahaan akan berubah. Artinya sinyal yang dipilih harus mengandung informasi agar mampu mengubah penilaian pihak eksternal terhadap perusahaan (Gumanti, 2009).

Jika pengumuman tersebut mengandung nilai positif, maka diharapkan pasar akan bereaksi pada waktu pengumuman tersebut diterima oleh pasar. Reaksi pasar ditunjukkan dengan adanya perubahan volume perdagangan saham.Pada waktu informasi diumumkan dan semua pelaku pasar sudah menerima informasi tersebut, pelaku pasar terlebih dahulu menginterpretasikan dan menganalisis informasi tersebut sebagai sinyal 
baik (good news) atau sinyal buruk (bad news). Hasil dari interpretasi informasi inilah nantinya yang akan mempengaruhi permintaan dan penawaran dari investor. Jika banyak investor berpandangan pesimis akibat bad news dari informasi yang diterima, maka ia akan mengurangi jumlah pembelian yang terjadi dan akan menambah penawaran di pasar sehingga harga akan terdorong turun. Sebaliknya jika investor memandang optimis akibat good news dari informasi yang diterima, maka ia akan menambah jumlah pembelian yang terjadi dan akan menurunkan penawaran di pasar sehingga harga akan terdorong naik (Yanti 2012)

\subsection{Dividen}

\subsubsection{Kebijakan Dividen}

Dalam teori Efficiency Market Hyphotesis, harga saham bereaksi terhadap informasi yang ada, termasuk didalamnya adalah informasi tentang pembagian deviden. Informasi tentang pembagian deviden dipercaya akan dapat mempengaruhi

perilaku harga saham di bursa akibat dari aksi investor yang menginginkan keuntungan dari kejadian (moment) tersebut. Kebijakan dividen adalah rencana tindakan yang harus diikuti dalam membuat keputusan dividen (Gitman, 2000). Kebijakan perusahaan dalam membayar dividen berbeda-beda. Berbeda dengan preferred stocks, pemegang saham biasa (common stock) umumnya menerima pembayaran yang didasarkan pada salah satu dari 3 jenis kebijakan dividen, yaitu:

a. Constant-Payout-Ratio Dividend Policy adalah kebijakan dividen yang didasarkan dengan persentase tertentu dari pendapatan,

b. Regular Dividend Policy adalah kebijakan dividen yang didasarkan atas pembayaran dividen dengan rupiah yang tetap dalam setiap periode. Seringkali kebijakan dividen teratur digunakan dengan memakai target rasio pembayaran dividen dan

c. Low-Regular-an-ExtraDividend Policy adalah kebijakan dividen yang didasarkan pembayaran dividen rendah yang teratur, ditambah dengan dividen ekstra jika ada jaminan pendapatan.

\subsection{Return Tidak Normal (Abnormal Return)}

Efisiensi pasar diuji dengan melihat return tidak normal (abnormal return) yang terjadi. Pasar dinyatakan tidak efisien jika satu atau beberapa pelaku pasar dapat menikmati return yang tidak normal dalam jangka waktu yang cukup lama. Studi peristiwa (event study) menganalisis abnormal return dari sekuritas yang mungkin terjadi di sekitar 
pengumuman suatu peristiwa. Return tidak normal atau abnormal return merupakan kelebihan dari return realisasi yang terjadi terhadap return normal. Dengan demikian abnormal return adalah selisih antara return realisasi dengan return ekspektasi. Return tidak normal dapat dihitung dengan rumus berikut (Reilly dan Brown, 2003) :

$A R_{i t}=R_{i t}-E\left(R_{i t}\right)$

Dimana:

$A R_{i t}=$ return tidak normal sekuritas i pada periode peristiwa ke $\mathrm{t}$

$R_{i t} \quad=$ return realisasi yang terjadi untuk sekuritas ke i pada periode peristiwa ke $\mathrm{t}$

$E\left(R_{i t}\right)=$ return ekspektasi sekuritas ke i untuk periode peristiwa ke $\mathrm{t}$

\subsection{Volume Perdagangan (Trading Volume Activity)}

Secara teoritis volume perdagangan terjadi disebabkan oleh faktor berikut ini, diantaranya: (1) kebutuhan investor yang besar akan likuiditas, (2) pengaruh informasi, seperti informasi yang dirilis ke publik, informasi prifat, informasi makro dan informasi spesifik perusahaan, (3) perbedaan opini atau kepercayaan investor. Chen et al., (2014) menemukan bahwa aktivitas perdagangan investor ditentukan oleh informasi pasar, informasi spesifik perusahaan dan tingkat kepercayaan yang berbeda di antara investor.

Perdagangan saham dapat terjadi jika para investor mempunyai kecermatan yang berbeda terhadap pengungkapan informasi yang mereka peroleh.Asimetri informasi sebelum informasi diumumkan,menyebabkan para investor membentuk kepercayaan (belief), dengan tingkat yang berbeda.Perbedaan bobot informasi publik yang baru diumumkan akan berakibat pada perbedaan perubahan kepercayaan investor yang mengakibatkan terjadinya perdagangan. Jadi reaksi volume perdagangan merupakan suatu fungsi peningkatanbaik perbedaaan kecermatan para investor maupun perubahan harga.

Volume perdagangan dihitung dengan cara membagi volume saham yang diperdagangkan pada periode ke-t dengan total saham perusahaan yang beredar pada waktu ke-t (Foster, 1986). Setelah TVA masing-masing perusahaan diketahui, kemudian dihitung rata-rata TVA untuk masing-masing hari selama periode pengamatan. Mengacu pada (Foster, 1986), volume perdagangan dapat dirumuskan dengan formula berikut: 
$T V A=\frac{\text { Jumlah saham } i \text { yang diperdagangkan pada waktu } t}{\text { Jumlah saham } i \text { yang beredar pada waktu } t}$

\subsection{Hipotesis Penelitian}

Hipotesis pada dasarnya adalah suatu anggapan yang mungkin benar dan sering digunakan sebagai dasar pembuatan keputusan, pemecahan persoalan maupun dasar penelitian lebih lanjut (J. Supranto, 2001:21). Anggapan sebagai satu hipotesis juga merupakan data tetapi karena kemungkinan dapat salah, apabila akan digunakan sebagai dasar pembuatan keputusan harus diuji dahulu dengan memakai data hasil observasi.

Adapun hipotesis dalam penelitian ini adalah :

$\mathrm{H} 1$ = Pengumuman dividen berpengaruh positif terhadap abnormal return saham

$\mathrm{H} 2$ = Pengumuman dividen berpengaruh positif terhadap volume perdagangan saham

\section{METODE PENELITIAN}

\subsection{Populasi dan Sampel}

Populasi penelitian ini adalah seluruh perusahaan yang mengumumkan akanmembayar dividen dan terdaftar di Bursa Efek Indonesia tahun 2015-2016.

Sampel merupakan bagian dari populasi yang diambil melalui cara-cara tertentu, jelas dan lengkap (Sekaran, 2006).Teknik pengambilan sampel dalam penelitian ini ditentukan berdasarkan purposive sampling method, yaitu teknik penentuan sampel dengan menggunakan pertimbangan dan batasan tertentu sehingga sampel yang dipilih relevan dengan tujuan penelitian. Kriteria yang digunakan untuk memilih sampel dalam penelitian ini, adalah:

1. Perusahaan mengumumkan dividen pada tahun 2015 sampai 2016.

2. Perusahaan tidak mempunyai pengumuman lain selain pengumuman dividen selama event window (11 hari), yaitu 5 hari sebelum dan 5 hari sesudah pengumuman dividen. Hal ini untuk menghindari adanya confounding effect akibat pengumuman lain seperti merger, akuisisi, right issue, stock split dan lain-lain.

3. Perusahaan manufaktur yang mengumumkan dividen tunai sekali dalam satu tahun dan berturut-turut selama periode 2015-2016. 


\section{Desain Penelitian}

Penelitian ini adalah jenis penelitian event study yang mengambil pengumuman dividensebagai event.Samsul (2006) menjelaskan event study merupakan penelitian yang mempelajari pengaruh suatu peristiwa terhadap harga saham di pasar, baik ketika peristiwa itu terjadi maupun beberapa waktu setelah peristiwa itu terjadi.Event studyakan melihat apakah harga saham mengalami peningkatan atau mengalami penurunan setelah suatu peristiwa terjadi.

Peristiwa tersebut memiliki karakteristik yang berbeda dan pengaruhnya terhadap harga saham juga berbeda.Peristiwa corporate action seperti pembagian dividen memiliki pengaruh terhadap harga saham. Sejak kapan dan sampai kapan sebuah peristiwa mempengaruhi harga saham pada setiap perusahaan juga berbeda-beda serta dampaknya juga tidak sama. Oleh sebab itu perlu menemukan tolak ukur terhadap dampak dari suatu peristiwa. Investor menggunakan "return" sebagai tolak ukurnya. Dalam event study yang mempelajari "peristiwa spesifik" abnormal return digunakan sebagai tolak ukur dampak sebuah peristiwa terhadap harga saham.

\section{Periode Pengamatan}

Periode pengamatan yang dilakukan dalam penelitian ini dibagi menjadi dua periode yaitu periode estimasi dan periode pengamatan (Jogyianto, 2012).Periode estimasi merupakan periode sebelum periode peristiwa.Periode pengamatan disebut juga dengan periode peristiwa atau periode jendela.Periode pengamatan diambil selama 11 hari yaitu mulai dari $\mathrm{t}-5$, $\mathrm{t}-0$ sampai $\mathrm{t}+5$. Tanggal pengumumandividen dinotasikan dengan $\mathrm{t}-0$.

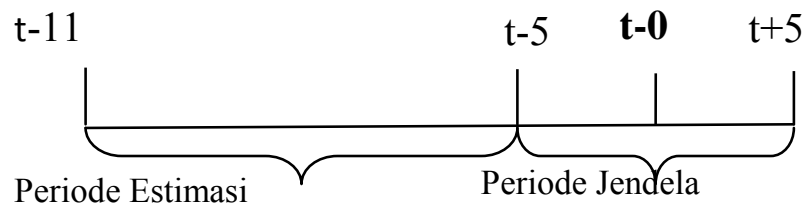




\subsection{Variabel Penelitian dan Defenisi Operasional Variabel Variabel independen}

Dividenmerupakan bagian laba perusahaan yang dibagikan kepada pemegang saham.Variabel ini menggunakan alat ukur berupa pengumuman. Pertama, dibutuhkan daftar perusahaan yang mengumumkan dividen pada satu tahun tertentu dapat dilihat darialamat website Bursa Efek Indonesia pada kolom pengumuman emiten. Dari situs tersebut akan diketahui tanggal informasi dirilis ke publik. Data lebih lanjut akan ditelusuri melalui laporan keuangan emiten. Hanya perusahaan yang mengumumkan pembagian dividen yang akan di analisis dalam penelitian ini yang digambarkan oleh abnormal return dan volume perdagangan saham dan dianalisis melalui pengujian event study.

\section{Variabel Dependen}

\section{Abnormal Return}

Return tidak normal atau excess return merupakan kelebihan dari return sesungguhnya atau melebihi return normal. Return normal merupakan return yang diharapkan (expected return) oleh investor. Dengan demikian return tidak normal adalah selisih antara return realisasi dengan return ekspektasi.

Tahapan-tahapan yang dilakukan untuk menghitung abnormal return mengacu pada Jogiyanto (2012) adalah sebagai berikut:

1. Menghitung return saham individu harian dengan rumus :

$$
R_{i t}=\frac{P_{i t}-P_{t-1}}{P_{t-1}}
$$

2. Menghitung expected return selama periode jendela dengan periode estimasi selama 100 hari.

$$
E(R)=\frac{\sum_{t=1}^{n} R i}{n}
$$

3. Menghitung abnormal return harian individu dengan menggunakan market model dengan rumus sebagai berikut :

$$
A R_{i t}=R_{i t}-E\left(R_{i t}\right)
$$

4. Menghitung rata-rata abnormal return harian seluruh saham dengan rumus sebagai berikut :

$$
A A R_{i t}=\frac{\Sigma A R_{i t}}{n}
$$


5. Menghitung Cumulative Average Abnormal return (CAAR) dengan persamaan berikut:

$$
C A A R=\sum_{i=1}^{n} C A R_{i t}
$$

\section{Volume Perdagangan}

Data volume perdagangan saham yang digunakan adalah data volume perdagangan saham harian perusahaan yang dijadikan sampel selama periode pengamatan.Setelah mengetahui volume perdagangan harian, tahap selanjutnya adalah menghitung perubahan aktivitas perdagangan saham dengan menggunakan volume perdagangan untuk masing-masing perusahaan.

Tahapan yang dilakukan untuk menghitung volume perdagangan mengacu pada Foster (1986) sebagai berikut:

1. Menghitung Trading Volume Activity (TVA) dilihat menggunakan rumus :

TVAit $=\frac{\mathrm{Vi}, \mathrm{t}}{\mathrm{Vm}, \mathrm{t}}$

2. Setelah TVA diketahui kemudian dihitung rata-rata volume perdagangan saham untuk semua sampel dengan rumus :

$$
A T V A=\frac{\sum_{i}^{n}={ }_{t} T V A_{i t}}{n}
$$

Dimana:

ATVA = Rata-rata volume perdagangan saham

$\sum_{i}^{n}={ }_{t} T V A_{i t}=$ Jumlah volume perdagangan saham perusahaan i pada waktu ke-t

$n \quad=$ Jumlah perusahaan

3. Menghitung Cumulative Average Trading Volume (CATVA) dengan persamaan berikut:

$$
C A T V A=\sum_{i=1}^{n} A T V A_{i t}
$$




\subsection{Pengujian Hipotesis}

\section{Abnormal return}

Pengujian statistik terhadap abnormal return adalah untuk melihat signifikansi abnormal return yang ada dalam periode peristiwa. Teknik pengujian yang dilakukan dengan uji regresi sederhana dengan langkah sebagai berikut :

a. Hipotesis pertama $=\mathrm{H} 1: \mathrm{CAAR}>0$

b. Kriteria pengujian :

$\mathrm{P}$ value $<0,05: \mathrm{H} 1$ diterima

$\mathrm{P}$ value $>0,05: \mathrm{H} 1$ ditolak

c. Menghitung nilai $t$ dengan menggunakan program IBM SPSS.

d. Membandingkan nilai $t$ dengan nilai $t$ tabel.

\section{Volume Perdagangan}

Pengujian statistik terhadap volume perdagangan saham adalah untuk melihat signifikansi volume perdagangan yang ada dalam periode jendela. Teknik pengujian dilakukan dengan uji regresi sederhana dengan langkah:

a. Hipotesis kedua $=\mathrm{H} 2$ : CATVA $>0$

Kriteria pengujian :

$\mathrm{P}$ value $<0,05: \mathrm{H} 2$ diterima

$\mathrm{P}$ value $>0,05: \mathrm{H} 2$ ditolak

b. Menghitung nilai $t$ dengan menggunakan program IBM SPSS

c. Membandingkan nilai thitung dengan nilai $t$ tabel.

\section{HASIL PENELITIAN DAN PEMBAHASAN}

\subsection{Gambaran Umum Sampel Penelitian}

Data pada penelitian ini merupakan data sekunder yang diperoleh dengan mengakses situs Bursa Efek Indonesia (BEI), Yahoo Financeserta mengakses pustaka Indonesian Capital Market Directory (ICMD). Data yang dibutuhkan dalam penelitian ini antara lain: daftar emiten yang melakukan pengumuman dividen diperoleh dari laporan tahunan (annual report) Bapepam/OJK, tanggal pengumuman dividen emiten ditelusuri dari laman Bursa Efek Indonesia (www.idx.co.id). Selanjutnya data harga saham dan volume perdagangan saham diakses dari laman Yahoo Finance (www.yahoofinance.com), dan yang terakhir data jumlah saham yang beredar diperoleh dari Indonesian Capital Market Directory (ICMD). 
Objek penelitian ini adalah seluruh emiten yang listing di Bursa Efek Indonesia.Pengambilan sampel dilakukan dengan menggunakan tehnik pengambilan sampel purposive sampling. Adapun populasi emiten yang mengumumkan dividen sepanjang penelitian ini adalah 140 emiten. Namun beberapa dari populasi tersebut akan dikeluarkan dari penelitian karena tidak memenuhi data yang dibutuhkan. Jumlah sampel penelitian adalah 119 perusahaan yang memenuhi kelengkapan dan kriteria data penelitian.

\subsection{Statistik Deskriptif}

Statistik deskriptif untuk keseluruhan data pengamatan dapat dirangkum dalam Tabel 5.2 berikut ini.

Tabel 5.2Statistik Deskriptif Abnormal Return Descriptive Statistics

\begin{tabular}{|l|r|r|r|r|r|}
\hline & $\mathrm{N}$ & Minimum & Maximum & \multicolumn{1}{c|}{ Mean } & Std. Deviation \\
\hline T5 & 119 &,- 2299 &, 0907 &,- 001488 &, 0276308 \\
T4 & 119 &,- 0570 &, 0908 &, 002569 &, 0183281 \\
T3 & 119 &,- 0503 &, 0908 &, 003401 &, 0188238 \\
T2 & 119 &,- 0644 &, 0908 &, 000353 &, 0202022 \\
T1 & 119 &,- 0750 &, 1953 &, 000725 &, 0316591 \\
T0 & 119 &,- 1310 &, 1908 &, 003619 &, 0365826 \\
TMin1 & 119 &,- 0606 &, 0885 &,- 000023 &, 0227530 \\
TMin2 & 119 &,- 0718 &, 0907 &,- 002110 &, 0220670 \\
TMin3 & 119 &,- 6975 &, 0812 &,- 005838 &, 0672941 \\
TMin4 & 119 &,- 0504 &, 1170 &, 002826 &, 0214582 \\
TMin5 & 119 &,- 0660 &, 1089 &, 004734 &, 0244675 \\
Valid N & 119 & & & & \\
(listwise) & & & & & \\
\hline
\end{tabular}

Sumber: data sekunder diolah 2018

Pengamatan dilakukan dalam jendela pengamatan (event window) 11 hari pengamatan yaitu lima hari sebelum pengumuman dan lima hari setelah pengumuman dividen. Abnormal return merupakan selisih antara return realisasi dengan return yang diharapkan oleh investor (expected return). Nilai minimum selama pengamatan adalah $-0,6975$ yaitu pada pengamatan hari ketiga (Tmin3). Nilai tertinggi tampak pada pengamatan hari pengumuman (T0) dan sehari setelah pengumuman yang disimbolkan dengan T1 yaitu 0,1908 dan 0,1953. Rata-rata abnormal returnmenunjukkan nilai yang negatif selama 3 (tiga) hari sebelum pengumuman, yaitu- $0,005838,-0,002110$, dan $-0,000023$. Selanjutnya rata- 
rata abnormal return menunjukkan angka yang positif pada hari pengumuman dan 4 (empat) hari setelah pengumuman dividen, masingmasing 0,003619 (T0), 0,000725 (T1), 0,000353 (T2), 0,003401 (T3), dan 0,002569 (T4).

Tabel 5.3 Statistik Deskriptif Trading Volume Activity Descriptive Statistics

\begin{tabular}{|l|r|r|r|c|r|}
\hline & $\mathrm{N}$ & Minimum & Maximum & Mean & Std. Deviation \\
\hline T5 & 119 &, 000000 &, 000051 &, 00000187 &, 000005236 \\
T4 & 119 &, 000000 &, 000046 &, 00000168 &, 000004986 \\
T3 & 119 &, 000000 &, 000040 &, 00000167 &, 000004549 \\
T2 & 119 &, 000000 &, 000021 &, 00000151 &, 000003301 \\
T1 & 119 &, 000000 &, 000020 &, 00000156 &, 000003303 \\
T0 & 119 &, 000000 &, 000025 &, 00000169 &, 000003678 \\
TMin1 & 119 &, 000000 &, 000024 &, 00000148 &, 000003404 \\
TMin2 & 119 &, 000000 &, 000019 &, 00000137 &, 000002687 \\
TMin3 & 119 &, 000000 &, 000026 &, 00000193 &, 000004232 \\
TMin4 & 119 &, 000000 &, 000019 &, 00000151 &, 000003122 \\
TMin5 & 119 &, 000000 &, 000016 &, 00000125 &, 000002606 \\
Valid N & 119 & & & & \\
(listwise) & & & & & \\
\hline
\end{tabular}

Sumber: data sekunder diolah 2018

Trading Volume Activity (TVA) digunakan untuk mengetahui volume perdagangan. TVA dihitung dengan membagi volume perdagangan saham dengan total saham perusahaan yang beredar. Tabel $4.3 \mathrm{di}$ atas menunjukkan bahwa nilai minimum TVA adalah 0,000000 dan merata pada seluruh jendela pengamatan 11 hari. Nilai maksimum TVA tinggi tampak pada pengamatan 3 (tiga) hari setelah pengumuman dividend dan nilai tertinggi tampak pada pengamatan hari ke lima (T5). Nilai maksimum masing-masing pengamatan tersebut adalah0,000040 (T3), 0,000046 (T4), dan 0,000051 (T5). Rata-rata TVA bernilai positif pada semua pengamatan dan tertinggi tampak pada pengamatan hari ke tiga sebelum pengumuman (TMin3) yaitu 0,00000193 . 


\subsection{Uji Normalitas}

\section{Tabel 5.4 Hasil Uji Normalitas}

Hypothesis Test Summary

\begin{tabular}{|c|c|c|c|c|}
\hline & Null Hypothesis & Test & Sig. & Decision \\
\hline 1 & $\begin{array}{l}\text { The distribution of AR is normal wit } \\
\text { mean } 0.01 \text { and standard deviation } \\
0.05 \text {. }\end{array}$ & $\begin{array}{l}\text { tDine-Sample } \\
\text { Kolmogorov- } \\
\text { Smirnov Test }\end{array}$ & .000 & $\begin{array}{l}\text { Reject the } \\
\text { null } \\
\text { hypothesis. }\end{array}$ \\
\hline 2 & $\begin{array}{l}\text { The distribution of TVA is normal } \\
\text { with mean } 0.00 \text { and standard } \\
\text { deviation } 0.00 \text {. }\end{array}$ & $\begin{array}{l}\text { Qne-Sample } \\
\text { Kolmogorov- } \\
\text { Smirnov Test }\end{array}$ & .000 & $\begin{array}{l}\text { Reject the } \\
\text { null } \\
\text { hypothesis. }\end{array}$ \\
\hline
\end{tabular}

Asymptotic significances are displayed. The significance level is, 05 .

Nilai Kolmogorov-Smirnov untuk variabel abnormal return (AR) meunjukkan signifikasnsi 0,000 yang berarti data terdistribusi normal pada level signifikasi 0.05.Hasil uji Kolmogorov-Smirnov untuk variabel volume perdagangan (TVA) menunjukkan nilai 0,000 , artinya variabel volume perdagangan terdistribusi normal.Dengan demikian dapat disimpulkan bahwa data yang digunakan dalam penelitian ini terdistribusi secara normal.

\subsection{Uji Hipotesis}

\subsubsection{Pengumuman Dividen Terhadap Abnormal return}

Tabel 5.5 berikut ini menyajikan data Avarge Abnormal Return (AAR) dan Cummulative Abnormal Return (CAAR) selama 11 hari pengamatan yaitu lima hari sebelum, hari pengumuman, hingga lima hari setelah pengumuman dividen.

Tabel 5.5Cummulative Abnormal Return (CAAR)

\begin{tabular}{|l|r|r|r|}
\hline Date & \multicolumn{1}{|l|}{ AR } & \multicolumn{1}{l|}{ AAR } & \multicolumn{1}{l|}{ CAAR } \\
\hline T5 & -0.17704279 & -0.0160948 & -0.0160948 \\
\hline T4 & 0.30565734 & 0.02778703 & 0.01169223 \\
\hline T3 & 0.40470745 & 0.03679159 & 0.04848382 \\
\hline T2 & 0.04194909 & 0.00381355 & 0.05229737 \\
\hline T1 & 0.08629875 & 0.00784534 & 0.06014271 \\
\hline T0 & 0.43069073 & 0.0391537 & 0.09929642 \\
\hline TMin1 & -0.00277658 & -0.0002524 & 0.099044 \\
\hline TMin2 & -0.25107741 & -0.0228252 & 0.07621878 \\
\hline TMin3 & -0.69473752 & -0.063158 & 0.01306082 \\
\hline TMin4 & 0.33632257 & 0.03057478 & 0.0436356 \\
\hline TMin5 & 0.56328713 & 0.05120792 & 0.09484352 \\
\hline
\end{tabular}

Sumber: data sekunder diolah 2018 
Tampak pada tabel di atas bahwa terdapat abnormal return yang negatif pada tiga hari pengamatan sebelum pengumuman dirilis. Pada pengamatan hari ke tiga sebelum pengumuman (TMin3) terdapat abnormal return sebesar-0.69473752. Pada jendela pengamatan hari kedua sebelum pengumuman (TMin2) nilai abnormal return adalah-0.2510774. Selanjutnya sehari sebelum pengumuman dividen (TMin1) nilai abnormal return adalah0.00277658. Walaupun abnormal return tersebut bernilai negatif, tetapi sesungguhnya nilainya mengalami peningkatan mendekati hari pengumuman dividen.

Abnormal return positif ditemukan tepat pada hari pengumuman dividend dan bertahan selama 4 (empat) hari setelah pengumuman dividen. Abnormal return tertinggi tampak pada saat pengumuman dividen yaitu senilai 0.43069073.Hal ini menunjukkan bahwa informasi pengumuman dividen dinilai sebagai "good news"dan langsung direspon oleh investor. Jendela pengamatan hari pertama setelah pengumuman (T1) menunjukkan abnormal return sebesar 0.08629875, hari kedua (T2) adalah 0.04194909, hari ketiga (T3) 0.40470745 dan hari keempat (T4) adalah 0.30565734 . Selanjutnya hari ke lima (T5) setelah pengumuman dividen terdapat abnormal return yang negatif yaitu 0.17704279 .

Artinya, tidak terdapat lagi abnormal return yang positif pada hari ke lima.

Kondisi tersebut mengindikasikan bahwa semua investor sudah memperoleh informasi sehingga tidak ada lagi abnormal return yang positif. Pada pasar yang efisien setengah kuat (semi-strong efficiency), investor tidak akan memperoleh abnormal return yang positif dalam jangka waktu lama, karena segera informasi akan tersebar kepada seluruh investor. Dengan demikian tidak ada lagi investor yang diuntungkan dengan informasi tersebut.

Untuk menguji pengaruh pengumuman dividen terhadap abnormal returndianalisis menggunakan uji satu sisi one sample t-test, yaitu pada prinsipnya menguji signifikansi abnormal return saham di sekitar pengumuman peristiwa. Hasil pengujian dapat dilihat pada Tabel 5.6 berikut: 
Tabel 5.6Hasil Uji Hipotesis 1

One-Sample Test

\begin{tabular}{|c|c|c|c|c|c|c|}
\hline & \multicolumn{6}{|c|}{ Test Value $=0$} \\
\hline & \multirow[t]{2}{*}{$\mathrm{T}$} & \multirow[t]{2}{*}{ Df } & \multirow[t]{2}{*}{ Sig. (2-tailed) } & \multirow[t]{2}{*}{$\begin{array}{c}\text { Mean } \\
\text { Difference }\end{array}$} & \multicolumn{2}{|c|}{$\begin{array}{l}95 \% \text { Confidence Interval of } \\
\text { the Difference }\end{array}$} \\
\hline & & & & & Lower & Upper \\
\hline T5 &,- 587 & 118 & ,558 &,- 0014878 &,- 006504 &, 003528 \\
\hline $\mathrm{T} 4$ & 1,529 & 118 & 129 &, 0025685 &,- 000759 & 005896 \\
\hline $\mathrm{T} 3$ & 1,971 & 118 &, 050 & ,0034009 &,- 000016 &, 006818 \\
\hline $\mathrm{T} 2$ & , 190 & 118 & ,849 &, 0003525 &,- 003315 & ,004020 \\
\hline T1 &, 250 & 118 & ,803 &, 0007252 &,- 005022 &, 006472 \\
\hline T0 & 1,079 & 118 & ,283 & ,0036192 &,- 003022 &, 010260 \\
\hline TMin 1 &,- 011 & 118 & 991 &,- 0000233 &,- 004154 & 004107 \\
\hline TMin2 & $-1,043$ & 118 & ,299 &,- 0021099 &,- 006116 & ,001896 \\
\hline TMin3 &,- 946 & 118 & ,346 &,- 0058381 &,- 018054 &, 006378 \\
\hline TMin4 & 1,437 & 118 & , 153 &, 0028262 &,- 001069 &, 006722 \\
\hline TMin5 & 2,110 & 118 &, 037 & 0047335 &, 000292 & 009175 \\
\hline
\end{tabular}

Sumber: data sekunder diolah 2018

Dari tabel di atas menunjukkan Average Abnormal Return (AAR) dalam pengamatan lima hari sebelum hingga lima hari sesudah penguman dividen. Pada saat pengumuman dividentidak terdapat pengaruh yang signifikan yang ditunjukkan dengan nilai t-tabel lebih besar dibandingkan nilai t-hitung $(1,657>1,079)$ dan tingkat signifikansi 0,283lebih besar dari $0,05(0,283>0,05)$. Hal ini mungkin diakibatkan karena informasi belum ditangkap oleh investor tepat pada pengumuman dividen.Reaksi yang positif dan signifikan ditemukan pada pengamatan hari ketiga (T3) setelah pengumuman dengan nilai t-hitung $(1,971)$ lebih besar dibandingkan dengan t-tabel $(1,657)$ dan tigkat signifikansi 0,050 lebih kecil atau sama dengan $0,05(0,50 \leq 0,05)$.Reaksi pasar yang positif menunjukkan bahwa pengumuman dividen dipandang sebagai good news oleh investor.

Reaksi pasar pada jendela pengamatan hari pertama (T1) dan (T2) ditunjukkan dengan nilai t-hitung masing-masing0,250 dan 0,190 lebih kecil dibandingkan t-tabel 1,657 dengan tingkat sigkat signifikansi 0,803 dan 0,849 lebih besar dari 0,05 dan dinyatakan tidak signifikan. Sebelum pengumuman dividen ditemukan bahwa reaksi pasar tidak signifikan. Tampak dari nilai thitung masing-masing sehari sebelum pengumuman (TMin1) -0,011, hari kedua (TMin2) sebelum pengumuman -1,043, hari ketiga (TMin3) sebelum pengumuman $-0,946$ dan hari keempat (TMin4) sebelum pengumuman 1,437 
lebih kecil dibandingkan dengan t-tabel 1,657. Data ini didukung oleh tingkat signifikansi masing-masing pengamatan adalah 0,991 (TMin1), 0,299 (TMin2), 0,346 (TMin3), dan 0,153 (TMin4) yang semuanya lebih besar dari 0,05 untuk dinyatakan signifikan.Reaksi yang tidak signifikan pada pengamatan sebelum pengumuman dividen menunjukkan bahwa terdapat harga saham yang rendah (undervalued) sebelum pengumuman dividen.

Hipotesis pertama telah dirumuskan bahwa terdapat abnormal return atas pengumuman dividenyang dilihat dari Cummulative Avarage Abnormal return lebih besar dari $0 \quad(C A A R>0)$ dan nilai t-hitung $>$ ttabel.Tampak dari tabel 4.5, nilai CAAR lebih besar dari 0 (CAAR $0.09484352>0)$ dan dari tabel 4.6 tampak bahwa nilai nilai t-hitung $(1,971)$ lebih besar dibandingkan dengan t-tabel $(1,657)$ dan tigkat signifikansi 0,050 lebih kecil atau sama dengan $0,05(0,50 \leq 0,05)$. Secara keseluruhan disimpulkan bahwa terdapat pengaruh pengumuman dividen terhadap abnormal return ditunjukkan dengan nilai CAAR yang positif dan signifikan. Dengan demikian dapat disimpulkan bahwa hipotesis pertama diterima.

\subsubsection{Pengumuman Dividen Terhadap Volume Perdagangan}

Tabel 5.7 di berikut ini menunjukkan nilai Avarage Trading Volume Activity (ATVA) dan Cummulative Avarege Trading Volume Activity (CATVA) dalam jendela pengamatan selama 11 hari pengamatan yaitu lima hari sebelum hingga lima hari sesudah pengumuman dividen dirilis ke pasar.Volume perdagangan paling rendah tampak pada pengamatan hari kelima (TMin5) sebelum pengumuman yaitu 0.00014889. Volume perdagangan yang rendah juga tampak pada pengamatan hari keempat (TMin4) sebelum pengumuman senilai 0.00017909 pengamatan hari kedua (TMin2) sebelum pengumuman 0.00016309, dan pengamatan sehari (TMin1) sebelum pengumuman dengan nilai 0.00017611. Volume perdagangan tersebut lebih rendah dibandingkan pada saat pengumuman dividen dengan TVA 0.00020055 (T0) dan beberapa hari berikutnya 
setelah pengumuman.Hal ini menunjukkan bahwa benar terdapat volume perdagangan yang rendah sebelum pengumuman dividen disampaikan ke publik.

Tabel 5.7Cummulative Average Trading Volume Activity (CATVA)

\begin{tabular}{|c|c|c|r|}
\hline Date & TVA & ATVA & \multicolumn{1}{c|}{ CATVA } \\
\hline T5 & 0.00022217 & $2.01972 \mathrm{E}-05$ & $2.01972 \mathrm{E}-05$ \\
\hline T4 & 0.00019954 & $1.81399 \mathrm{E}-05$ & $3.83371 \mathrm{E}-05$ \\
\hline T3 & 0.00019911 & $1.81011 \mathrm{E}-05$ & $5.64382 \mathrm{E}-05$ \\
\hline T2 & 0.00018011 & $1.63736 \mathrm{E}-05$ & $7.28118 \mathrm{E}-05$ \\
\hline T1 & 0.00018541 & $1.68556 \mathrm{E}-05$ & $8.96674 \mathrm{E}-05$ \\
\hline T0 & 0.00020055 & $1.82318 \mathrm{E}-05$ & 0.000107899 \\
\hline TMin1 & 0.00017611 & $1.60096 \mathrm{E}-05$ & 0.000123909 \\
\hline TMin2 & 0.00016309 & $1.48264 \mathrm{E}-05$ & 0.000138735 \\
\hline TMin3 & 0.00022917 & $2.08336 \mathrm{E}-05$ & 0.000159569 \\
\hline TMin4 & 0.00017909 & $1.6281 \mathrm{E}-05$ & 0.00017585 \\
\hline TMin5 & 0.00014889 & $1.35351 \mathrm{E}-05$ & 0.000189385 \\
\hline
\end{tabular}

Sumber: data sekunder diolah 2018

Selanjutnya terjadi peningkatan volume perdagangan setelah pengumuman dividen disampaikan ke pasar.Tampak volume perdagangan menjadi 0.00018541 hari pertama (T1) setelah pengumuman , 0.00018011 hari kedua (T2) setelah pengumuman, 0.00019911 hari ketiga (T3) setelah pengumuman, 0.00019954 hari keempat (T4) setelah pengumuman, dan 0.00022217 hari kelima (T5) setelah pengumuman dividen.Hal ini mengindikasikan bahwa telah terjadi peningkatan volume perdagangan setelah pengumuman dividen diumumkan ke publik. Secara keseluruhan tampak pada tabel di atas bahwa nilai CATVA sebesar $0.000189385>0$ dengan demikian dapat dinyatakan terdapat pengaruh pengumuman dividen terhadap volume perdagangan. 
Tabel 5.8 Hasil Uji Hipotesis 2

One-Sample Test

\begin{tabular}{|c|c|c|c|c|c|c|}
\hline & \multicolumn{6}{|c|}{ Test Value $=0$} \\
\hline & \multirow[t]{2}{*}{$\mathrm{T}$} & \multirow[t]{2}{*}{ Df } & \multirow[t]{2}{*}{$\begin{array}{l}\text { Sig. (2- } \\
\text { tailed) }\end{array}$} & \multirow[t]{2}{*}{$\begin{array}{c}\text { Mean } \\
\text { Difference }\end{array}$} & \multicolumn{2}{|c|}{$\begin{array}{l}\text { 95\% Confidence Interval of the } \\
\text { Difference }\end{array}$} \\
\hline & & & & & Lower & Upper \\
\hline T5 & 3,890 & 118 & ,000 & ,000001867 & $9,2 \mathrm{E}-7$ &, 00000282 \\
\hline $\mathrm{T} 4$ & 3,668 & 118 &, 000 & ,000001677 & $7,7 \mathrm{E}-7$ &, 00000258 \\
\hline $\mathrm{T} 3$ & 4,013 & 118 &, 000 & ,000001673 & $8,5 \mathrm{E}-7$ &, 00000250 \\
\hline $\mathrm{T} 2$ & 5,001 & 118 &, 000 &, 000001514 & $9,1 \mathrm{E}-7$ & ,00000211 \\
\hline $\mathrm{T} 1$ & 5,144 & 118 & ,000 &, 000001558 & $9,6 \mathrm{E}-7$ & ,00000216 \\
\hline T0 & 4,998 & 118 &, 000 & ,000001685 & ,00000102 & ,00000235 \\
\hline TMin1 & 4,743 & 118 &, 000 &, 000001480 & $8,6 \mathrm{E}-7$ &, 00000210 \\
\hline TMin2 & 5,563 & 118 &, 000 & ,000001370 & $8,8 \mathrm{E}-7$ & ,00000186 \\
\hline TMin3 & 4,963 & 118 &, 000 & ,000001926 & ,00000116 & ,00000269 \\
\hline TMin4 & 5,259 & 118 & ,000 & ,000001505 & $9,4 \mathrm{E}-7$ & ,00000207 \\
\hline TMin5 & 5,236 & 118 &, 000 &, 000001251 & $7,8 \mathrm{E}-7$ & ,00000172 \\
\hline
\end{tabular}

Sumber: data sekunder diolah 2018

Ringkasan hasi uji hipotesis 2 menunjukkan bahwa terdapat nilai TVA yang positif pada semua pengamatan, sejak lima hari sebelum pengumuman (TMin5) hingga lima hari sesudah pengumuman (T55) dividen dirilis ke pasar. Tampak dari nilai t-hitung masing-masing $(5,236)$, $(5,259),(4,963),(5,563),(4,743),(4,998),(5,144),(5,001),(4,013),(3,668)$, $(3,890)$ lebih besar dibandingkan dengan t-tabel 1,657dan tingkat signifikansi semua pengamatan lebih kecil dari 0.05. Seluruh pengamatan menunjukkan nilai ATVA yang positif dan signifikan.

Seperti yang telah dijelaskan pada Tabel 5.8 di atas bahwa nilai CATVA sebesar $0.000189385>0$ diikuti dengan uji one sample t-test pada Tabel 5.9 menunjukkan nilai t-hitung4,998lebih besar dibandingkan dengan nilai t-tabel1,657dan tingkat signifikansi (0.000) lebih kecil dari 0.05 . Merujuk pada apa yang telah dirumuskan dalam hipotesis penelitian bahwa jika CATVA $>0$ dan nilai t-hitung lebih besar dibandingkan dengan t-tabel, maka dapat dinyatakan bahwa hipotesis diterima. Dengan demikian dapat disimpulkan bahwa hipotesis keduaditerima.

\section{PEMBAHASAN}

\subsubsection{Pengaruh Pengumuman Dividen Terhadap Abnormal Return}

Berdasarkan hasil pengujian hipotesis pertama yang menggunakan uji one sample t-test dari sampel perusahaan yang mengumumkan dividen menunjukkan, terdapat abnormal return harian di sekitar pengumuman 
peristiwa, yaitu lima hari sebelum hingga lima hari sesudah pengumuman dividen dirilis ke pasar. Nilai CAAR yang lebih besar dari nol menunjukkan nilai abnormal return yang positif dan nilai t-tabel lebih besar dibandingkan dengan nilai t-hitung dan signifikan. Hasil uji satu sisi one sample t-test mengkonfirmasi penelitian Abreau dan Gulamhussen (2013), Dharmarathne (2013), Aamir dan Shah (2011), Akbar dan Baig (2010), How et al. (2005) yang menemukan bahwa terdapat abnormal return yang signifikan positif pada peristiwa di sekitar pengumuman dividen.

Penerimaan hipotesis pertama membuktikan bahwa pengumuman dividen memiliki pengaruh terhadap abnormal return saham perusahaan. Ditandai dengan terdapat abnormal return yang positif dan signifikan. Artinya harga saham perusahaan setelah pengumuman meningkat sehingga terdapat tambahan kekayaan bagi investor. Selain itu, dapat dibuktikan bahwa pengumuman dividen dapat menaikkan harga saham yang undervalued. Tabel 5.5 menunjukkan bahwa terdapat abnormal return yang negatif pada pengamatan sebelum pengumuman dividen dan didukung oleh hasil uji hipotesis pada Tabel 5.6, nilai abnormal return yang negatif berarti harga saham perusahaan benar sedang rendah (undervalued) sebelum pengumuman dividen. Sesuai dengan hasil penelitian Baker et al., (2003) menyebutkan bahwa perusahaan akan mengumumkan dividen ketika harga saham sendang rendah (undervalued). Dengan demikian pengumuman dividen dapat menjadi alternatif bagi perusahaan untuk menaikkan harga saham. Hasil pengamatan tersebut dapat diterjemahkan bahwa para pelaku pasar mampu menerima sinyal informasi yang diberikan oleh perusahaan, dalam hal ini pengumuman dividen, dengan harapan akan mendapat return yang menguntungkan dari adanya transaksi tersebut. Temuan ini juga sejalan dengan temuan Lee et al., (2010) bahwa manager mengumumkan dividen dalam rangka meningkatkan harga saham yang pada akhirnya dapat meningkatkan kekayaan investor.

\subsubsection{Pengaruh Pengumuman Dividen Terhadap Volume Perdagangan}

Berdasarkan hasil pengujian hipotesis ketiga menggunakan uji one sample t-test dari sampel perusahaan yang mengumumkan dividen menunjukkan, terdapat peningkatan volume perdagangan harian di sekitar pengumuman peristiwa, yaitu lima hari sebelum hingga lima hari sesudah pengumuman dividen dirilis ke pasar. Tabel 5.7 menunjukkan nilai CATVA lebih besar dari nol dan Tabel 5.8 menunjukkan nilai t-tabel lebih 
besar dibandingkan dengan nilai t-hitung dan signifikan.Dengan demikian hipotesis kedua yang dirumuskan bahwa pengumuman dividenberpengaruh positif terhadap volume perdagangan diterima.

Dari Tabel 5.8 telah tampak bahwa volume perdagangan saham sebelum pengumuman lebih kecil dibandingkan dengan volume perdagangan setelah pengumuman disampaikan ke publik.Dengan demikian terjadi peningkatan volume perdagangan dari pengamatan setelah pengumuman dividen diketahui oleh pasar.Artinya pengumuman dividen memberikan manfaat yang baik bagi perusahaan yang ditunjukkan dengan adanya peningkatan volume perdagangan.Hasil penelitian yang positif dan signifikan mengindikasikan bahwa investor dapat menangkap sinyal yang diberikan oleh perusahaan. Melalui pengumuman dividen, harga saham akan meningkat sehingga return yang diterima investor juga akan positif yang pada akhirnya juga akan mempengaruhi aktivitas perdagangan di pasar modal.

Peningkatan volume perdagangan setelah pengumuman dividen mengindikasikan bahwa event tersebut dipandang informatif oleh investor sehingga mempengaruhi volume perdagangan saham di pasar modal.Volume perdagangan merupakan sebuah ukuran untuk melihat informasi yang terkandung dalam sebuah pengumuman publik.Hal ini sesuai dengan temuan Barron dan Karpoff (2004) bahwa volume perdagangan yang tinggi merupakan indikasi bahwa sebuah pengumuman mengandung informasi.Kondisi ini memberikan gambaran bahwa perusahaan berhasil memberikan sinyal positif ke pasar ditandai dengan respon positif investor yang dapat dilihat dari peningkatan volume perdagangan saham.

\section{KESIMPULAN DAN SARAN}

\subsection{Kesimpulan}

Penelitian ini digunakan untuk menganalisis pengaruh pengumuman dividen terhadap abnormal return dan volume perdagangan di sekitar pengumuman. Berdasarkan hasil penelitian yang telah dilakukan terhadap keempat hipotesis yang diuji dengan menggunakan uji satu sisi one sample t-test diperoleh kesimpulan sebagai berikut:

1. Pengumuman dividen berpengaruh positif terhadap abnormal return

2. Pengumuman dividen berpengaruh positif terhadap volume perdagangan saham 


\subsection{Keterbatasan dan Saran}

1. Penelitian selanjutnya dapat menganalisis faktor-faktor yang mempengaruhi perusahaan mengumumkan dividen.

2. Penelitian ini menggunakan event study untuk melihat reaksi pasar atas pengumuman dividen dalam 11 hari (window event), penelitian selanjutnya dapat menganalisis pengamatan yang lebih panjang.

\section{DAFTAR PUSTAKA}

Abreau J.F. dan M.A. Gulamhussen. 2013. Dividend Payouts: Evidence from U.S. Bank Holding Companiesin the Context of the Financial Crisis. Journal of Corporate Finance 22, 54-65

Akbar M. dan H.H. Baig. 2010. Reaction of Stock Prices to Dividend Announcements andMarket Efficiency in Pakistan. The Lahore Journal of Economics15(1), 103-125

Amir M. dan S.Z.A. Shah. 2011. Dividend Announcements and the Abnormal Stock Returns for the Event Firm and Its Rivals. Australian Journal of Business and Management Research 1,(8), 72-76

Asquith, P. and D. Mullins. 1983. The Impact of Initiating Dividend Payments onShareholders' Wealth. The Journal of Business, 56 (1), $77-96$

Aharony, J. and I. Swary. 1980. Quarterly dividend and earnings announcements and stockholders' returns: an empirical analysis, Journal of Finance 35, 1-12.

Baker, H. K, \& Powell, G. E. 2012. Dividend Policy in Indonesia: Survey Evidence From Executives. Journal Asia Business Studies 6(1), 79-92

Dharmarathne.D.G. 2013.Stock Price Reaction to Dividen Announcements and Information Efficiency in Sri Lankan Share Market. International Journal of Research In Social Sciences Vol. 3, No.2

Fama, E.F. 1970. Efficient Capital Markets: A Review of Theory and Empirical Work, The Journal of Finance 25(2), 383-417

Fama, E.F., L. Fisher, M.C. Jensen and R. Roll. 1969. The Adjustment of Stock Prices to New Information, International Economic Review 10(1), 1-21. 
Foster, George, 1986, Financial Statement Analysis, Second Edition,. Singapore: Prentice-hall

Gitman, L.J. 2000. "Principles of Managerial Finance 9th Edition", USA: Addison Wesley Publishing Company.

Gumanti, Tatang A. 2009. Teori Sinyal dalam Manajemen Keuangan. Usahawan No.06 XXXVIII

Gumanti T.A. dan Utami E.S. 2002.Bentuk Pasar Efisien dan Pengujiannya. Jurnal Akuntansi \& Keuangan Vol. 4, No. 1, Mei 2002: $54-68$

How J.C.Y, P. Perhoeven dan C.X. Huang. 2005. Information Asymmetry Surrounding Earnings and DividendAnnouncements: An Intra-day Analysis Mathematics and Computers in Simulation 68, 463-473

Husnan, Suad. 2005. Dasar-Dasar Teori Portofolio dan Analisis Sekuritas. Yogyakarta: UPP AMP YKPN

Jogiyanto. 2008. Teori Portofolio dan Analisis Investasi. Fakultas Ekonomika dan Bisnis Universitas Gadjah Mada

Lonie, A.A. Abeyratna, G. Power, D.M. Sinclair, C.D. 1996. "The Stock Market Reaction to Dividend Announcements: A UK Study of Complex Market Signals", Journal of Economic Studies, 23 ( 1),3252.

Menike. 2014. Stock Price Reactions to the Dividend Announcement in the Emerging Market: Case in the Colombo Stock Exchange Sri Lanka. European Journal of Business and Management Vol.6, No.12, 2014

Ratnawati, Sumiati dan I. Triyuono. 2009. Analisa Dampak Pengumuman Dividen Terhadap Return, Variabilitas dan Tingkat Keuntungan dan Aktivitas Volume Perdagangan Saham. Wacana Vol 12 No. 4

Reilly dan Brown. 2003. Investment Analysis Portofolio Management.

Robert Kaestner and Feng-Ying Liu. 1998. New Evidence on The Information Content of Dividend Announcements, the Quarterly Review of Economics and Finance, 38, 2, 251-274.

Sadikin, Ali. 2011. Analisis Abnormal Return dan Volume Perdagangan Saham Sebelum dan Sesudah Peristiwa Pemecahan Saham Sebelum dan Sesudah Peristiwa Pemecahan Saham (Studi Pada Perusahaan yang Go Publik di Bursa Efek Indonesia). Jurnal Manajemen dan Akuntansi Volume 12 No.1 
Samsul, Mohamad. 2006. Pasar Modal dan Manajemen Portofolio. Jakarta: Erlangga

Sekaran, Uma. 2006. Metodologi Penelitian untuk Bisnis. Jakarta: Salemba Empat.

Siaputra, L.,dan A. S. Atmadja. 2006. Pengaruh Pengumuman Dividen Terhadap Perubahan Harga Saham Sebelum dan Sesudah Ex-Dividend Date di Bursa Efek Indonesia (BEI) Jurnal Akuntansi dan Keuangan, Vol. 8, No. $1: 71-77$

Sularso, R. Andi, Pengaruh Pengumuman Dividen Terhadap Perubahan Harga Saham (Return) Sebelum dan Sesudah Ex-Dividend Date di Bursa Efek Indonesia (BEI)

Weston, Fred J. and Brigham, Eugene F. (1993), Manajemen Keuangan Jilid 2, Jakarta, Erlangga.

Yanti. 2012. Pengujian AbnormalReturn Saham Sebelum dan Sesudah Peluncuran Indeks Saham Syariah Indonesia. Jurnal Manajemen, Vol 1, N0.01 